\title{
PENGAKUAN ASET TAK BERWUJUD DAN PERBANDINGAN METODE GARIS LURUS DENGAN METODE SALDO MENURUN DALAM MENENTUKAN PAJAK PENGHASILAN
}

\author{
Puji Rahayu, Hariana Septian \\ Universitas Islam Kadiri, Kediri, Indonesia \\ pujirahayu@uniska-kediri.ac.id, harianaseptian@gmail.com \\ https://doi.org/10.46367/jas.v4i2.253
}

Received: Nov 07, 2020 Revised: Dec 01, 2020 Accepted: Dec 10, 2020 Published: Dec 16, 2020

\begin{abstract}
The purpose of this study is to analyze the recognition of intangible assets and to compare the straights line method with the declining balance method in determining income tax. The method in this research is evaluation and qualitative research type. From the results of the research, it was identified that the company has intangible assets in the form of a personnel information system worth IDR 35,000,000, all costs used to obtain the system are recognized as intangible assets according to the criteria for intangible assets according to PSAK 19. Amortization calculation results in 2019 using the straight-line method amounted to IDR 8,750,000. So that the commercial comprehensive income generated is IDR 27,425,574,392. Meanwhile, the declining balance method resulted in amortization of IDR 17,500,000 and the resulting comprehensive commercial profit of IDR 27,416,824,392. After the fiscal reconciliation was carried out, the Income Tax amounted to IDR 6,285,027,465 using a straight line as the amortization calculation. Meanwhile, Income Tax with amortization costs uses the declining balance method of IDR 6,282,964,965. There is a tax savings of IDR 2,062,500 if you use the Decreasing Balance Method. So that the declining balance method is very suitable to use when economic conditions are sluggish like today due to the impact of Covid-19. The tax savings can be used to increase the company's capital to run business operations.
\end{abstract}

Keywords: Intangible Assets, Straights Line, Declining Balance, Income Tax.

\begin{abstract}
ABSTRAK
Tujuan dari penelitian ini untuk untuk menganalisis pengakuan aset tak berwujud dan membandingkan metode garis lurus dengan metode saldo menurun dalam menentukan pajak penghasilan. Metode dalam penelitian ini adalah evaluasi dan jenis penelitian kualitatif. Dari hasil penelitian, diidentifikasi perusahaan memiliki aset tak berwujud berupa sistem informasi kepegawaian senilai Rp 35.000.000,-, seluruh biaya yang digunakan untuk memperoleh sistem tersebut diakui sebagai aset tak berwujud sudah sesuai dengan kriteria aset tak berwujud menurut PSAK 19. Hasil perhitungan amortisasi pada tahun 2019 dengan menggunakan metode garis lurus yaitu sebesar Rp 8.750.000. Sehingga laba komprehensif komersial yang dihasilkan sebesar Rp 27.425.574.392. Sedangkan metode saldo menurun dengan hasil amortisasi sebesar Rp 17.500.000 dan laba komprehensif komersial
\end{abstract}


yang dihasilkan sebesar Rp 27.416.824.392. Setelah dilakukan rekonsiliasi fiskal, Pajak Penghasilan sebesar Rp 6.285.027.465 jika menggunakan garis lurus sebagai penghitungan amortisasi. Sedangkan Pajak Penghasilan dengan biaya amortisasi menggunakan metode saldo menurun senilai $\mathrm{Rp}$ 6.282.964.965. Terdapat penghematan pajak sebesar Rp 2.062.500 jika menggunakan Metode Saldo Menurun. Sehingga metode saldo menurun sangat sesuai digunakan saat kondisi perekonomian sedang lesu seperti saat ini karena dampak covid-19. Penghematan pajak tersebut bisa digunakan sebagai penambah modal perusahaan untuk menjalankan operasional usaha.

Kata Kunci: Aset Tak Berwujud, Garis Lurus, Saldo Menurun, Pajak Penghasilan.

\section{PENDAHULUAN}

Seiring dengan perkembangan zaman yang semakin modern dan membuat dunia bisnis semakin berkembang dengan cepat, sumber-sumber sebagai informasi bisnis juga harus ikut berkembang. Supaya informasi dapat terlaksana dengan efisien maka alat informasi juga harus berevolusi. Semula penyusunan informasi masih manual maka dituntut menggunakan digital agar penyajian laporan keuangan lebih berkualitas, rasional, objektif dan memudahkan pemakai laporan keuangan mengambil keputusan. Namun sistem digital yang canggih harus di dukung dengan sumber daya manusia yang handal pula. Intellectual capital sangat mempengaruhi nilai perusahaan (Imaningarti and Sari 2015). Hal ini merupakan tuntutan yang wajar, agar manajemen akan terus mengupgrade ilmunya sehingga laporan keuangan yang disusun sesuai dengan Pedoman Standart Akuntansi Keuangan (PSAK) terbaru. Salah satu pembahasan dalam PSAK terbaru yakni PSAK 19 tentang aset tak berwujud.

Aset tak berwujud dibagi menjadi dua kelompok besar yaitu dapat di indentifikasi dan tidak dapat di identifikasi (Riahi and Belkaoui 2011). Perlakuan akuntansi untuk aset tak berwujud tidak semudah aset berwujud atau aset tetap, karena sifatnya yang tidak berwujud. Seringkali terjadi konflik antara pengakuan aset tak berwujud tersebut diakui sebagai aset tetap atau aset tak berwujud, atau bahkan diakui sebagai biaya. Permasalahan yang sering muncul disebabkan karena aset tak berwujud tersebut dihasilkan oleh internal sehingga kesulitan menentukan biaya historis yang digunakan sebagai pengukuran nilai aset tak berwujud tersebut. Jika aset tersebut diperoleh dari pihak eksternal pun harus dipilah dulu, karena aset tak berwujud yang melekat pada aset tertentu maka diakui sebagai aset tetap. Sedangkan untuk penilaian aset tak berwujud yang diperoleh dari pihak lain dicatat senilai biaya perolehannya (Warren et al. 2014). Seperti hasil penelitian berikut biaya situs web bukan diakui sebagai beban namun seharusnya diakui sebagai aset tak berwujud (Sofia 2018). Penelitian lain menunjukan bahwa biaya yang dikeluarkan untuk seluruh proses produksi aplikasi dicatat sebagai biaya bukan dikapitalisasi sebagai aset tak berwujud (Firmansyah and Hartanto 2019). Perbedaan antara pengakuan aset tak berwujud tersebut sangat mempengaruhi penyajian dalam laporan keuangan, sehingga berpengaruh pula dalam perhitungan amortisasi.

Amortisasi merupakan pengalokasian untuk aset tak berwujud selama masa manfaat dapat di depresiasikan (Hermawan et al. 2019). Pembebanannya harus secara tepat berdasarkan estimasi umur manfaatnya, sehingga sesuai dengan 
konsep dari matching principle (Firmansyah and Nurwati 2020). Bagi aset tak berwujud yang tidak dapat diidentifikasi atau memiliki umur manfaat tidak terbatas. Berdasarkan komersial atau PSAK 19 tidak dilakukan amortisasi, namun disyaratkan melakukan pengujian untuk penurunan nilai setiap tahun dengan cara membandingkan jumlah terpilih dengan jumlah tercatat. Salah satu penelitian menggunakan pendekatan kapitalisasi-amortisasi yang menyatakan bahwa pendekatan amortisasi memiliki hubungan antara laba akuntansi (Suryandari and Yunitha 2011). Berbeda dengan hasil penelitian lain yang menyatakan bahwa beban amortisasi aset tidak berwujud yang disajikan dalam laporan keuangan memiliki nilai negatif terhadap nilai pasar ekuitas (Setijawan 2011). Sedangkan untuk aset tak berwujud yang dapat diidentifikasi atau memiliki masa manfaat terbatas secara komersial atau berdasarkan PSAK 19 ada tiga metode amortisasi yaitu metode garis lurus, metode saldo menurun, dan metode unit produksi. Salah satu penelitian menyatakan aset tak berwujud seperti piranti lunak dan lisensi dengan menggunakan metode garis lurus akan menghasilkan laba komersial lebih banyak (Firmansyah et al. 2020). Beda pengakuan jenis aset tak berwujud berbeda pula penentuan metode amortisasi yang digunakan sebagai pembebanan. Namun metode amortisasi yang digunakan dalam laporan laba rugi menurut PSAK 19 Tahun 2018 atau disebut komersial tidak semuanya diakui oleh UU PPh sebagai dasar perhitungan pajak.

Pajak merupakan iuran atau kewajiban menyerahkan sebagian harta kepada negara. Dengan kata lain sebagian daya beli rakyat ditarik oleh pemerintah untuk Negara (Bohari 2012). Sebelum menghitung pajak penghasilan pihak manajemen akan melakukan perencanaan pajak dengan mencari celah dalam peraturan perpajakan melalui memaksimalkan penghasilan yang dikecualikan atau meminimalkan biaya yang tidak diperkenankan sebagai pengurang pajak serta pemilihan metode akuntansi (Rori 2013). Metode akuntansi yang dimaksud salah satunya adalah metode penyusutan aset tak berwujud atau amortisasi. Mengacu pada pasal 11A ayat 2 UU PPh No. 36 Tahun 2008, metode amortisasi yang digunakan sebagai penentuan pajak penghasilan perusahaan yaitu metode garis lurus dan metode saldo menurun (Kemensekneg RI 2008). Adanya perbedaan metode amortisasi secara akuntansi yang selanjutnya disebut amortisasi komersial dengan metode amortisasi secara pajak yang selanjutnya disebut amortisasi fiskal. Perbedaan ini akan mengakibatkan timbulnya selisih nilai biaya amortisasi menurut perhitungan komersial dengan biaya amortisasi yang dihitung berdasarkan peraturan perundang-undangan perpajakan atau fiskal. Sehingga akan menimbulkan perbedaan dalam menghitung besarnya Penghasilan Kena Pajak (PKP). Besarnya PKP sangat mempengaruhi besarnya pajak penghasilan yang akan dibayar oleh perusahaan (Ainiyah 2018). Pengetahuan yang baik tentang peraturan perpajakan agar perusahaan tidak terjebak dalam penyelundupan pajak atau melanggar ketentuan pajak, sehingga perusahaan akan menanggung konsekuensinya (Sugeng 2011). Seperti PT. XYZ dalam menyusun laporan keuangan fiskal, perusahaan belum sesuai dengan UU No. 36/2008 sehingga berdampak pada perhitungan pajak penghasilan (Wijaya and Widjaja 2019). Sama halnya dengan yang dilakukan oleh PT. AV dalam menyusun SPT Tahunan Badan, akibat kesalahan pembebanan biaya menimbulkan selisih kurang bayar dan menimbulkan kerugian bagi perusahaan karena harus membayar sanksi dan denda (Dewi and Setiawan 2015). Pentingnya pemahaman tentang SAK dan 
Peraturan Perpajakan agar perhitungan pajak penghasilan tepat dan terhindar dari sanksi atau denda serta penghematan pajak pun bisa dilakukan oleh perusahaan.

PT. Petrokopindo Cipta Selaras Gresik merupakan perusahaan di bidang usaha logistik. Lingkup usahanya antara lain angkutan darat, pergudangan, usaha perdagangan umum dan jasa persewaan alat berat serta perbengkelan. Aktivitas perusahaan tidak terlepas dari penggunaan aset tak berwujud. Aset tak berwujud yang diakui oleh perusahaan adalah perangkat lunak. Aset tak berwujud tersebut dalam setiap periode akan mengalami penurunan nilai manfaat maka akan dilakukan penghitungan amortisasi setiap akhir periode. Metode amortisasi yang digunakan antara PSAK dengan Peraturan Perpajakan kemungkinan berbeda sehingga harus dilakukan rekonsiliasi fiskal, karena pembebanan tersebut akan mempengaruhi penyajian dalam laporan keuangan fiskal yang digunakan sebagai dasar penentuan pajak penghasilan. Oleh sebab itu penelitian ini bertujuan untuk menganalisis pengakuan aset tak berwujud dan membandingkan metode garis lurus dengan metode saldo menurun dalam menentukan pajak penghasilan.

\section{TELAAH LITERATUR}

\section{Aset Tak Berwujud}

Menurut Peraturan Standar Akuntansi Keuangan atau PSAK 19 Revisi 2018 definisi aset tak berwujud adalah "Aset nonmoneter teridentifikasi tanpa wujud fisik". Sedangkan menurut para ahli aset tak berwujud didefinisikan sebagai berikut: Menurut Jusuf (2011) bahwa aset tak berwujud adalah hak, hak istimewa, dan keuntungan kompetitif yang timbul dari pemilikan aset jangka panjang yang tidak memiliki substansi fisik (tidak berwujud). Menurut Kieso (2017) bahwa aset tak berwujud memiliki tiga karakteristik antara lain aset tersebut dapat diidentifikasi, tidak memiliki eksistensi fisik, dan bukan merupakan aset moneter. Sedangkan menurut Martani et al. (2017) bahwa aset tidak berwujud adalah aset nonmoneter yang teridentifikasi tanpa wujud fisik. Beberapa karakteristik utama yaitu dapat diidentifikasi, kendali dan tidak mempunyai wujud fisik.

Aset tak berwujud akan diakui bila kriteria utama berikut terpenuhi: (1) Aset tak berwujud dapat diidentifikasi secara terpisah dari aspek entitas lain. (2) Penggunaan aset tak berwujud dikendalikan oleh entitas sebagai akibat dari tindakan atau kejadian dimasa lalu. (3) Terdapat manfaat ekonomi dimasa mendatang yang mengalir ke entitas. (4) Biaya perolehan aset dapat diukur secara andal (Kartikahadi et al. 2016).

Berikut ini perlakuan akuntansi untuk perangkat lunak komputer, terdapat beberapa alternatif perlakuan akuntansi: (1) Pada perusahaan pengembangan perangkat lunak. Biaya penelitian yang timbul selama mengembangkan program perangkat lunak harus dibebankan. Sedangkan biaya yang timbul dalam fase pengembangan dapat dikapitalisasi apabila memenuhi kriteria utama pengakuan aset tak berwujud. (2) Perangkat lunak yang dikembangkan untuk digunakan secara internal, semua biaya harus dibebankan. Karena entitas kesulitan untuk menunjukan program tersebut dapat memberikan manfaat ekonomi dimasa depan bagi entitas. (3) Perangkat lunak yang dibeli untuk dijual diakui sebagai persediaan. Perangkat lunak yang dimiliki untuk dijual hak pakainya atau disewakan ke pihak lain maka harus diakui sebagai aset tak berwujud. Sedangkan 
perangkat lunak yang dibeli untuk dipergunakan sendiri dan merupakan bagian integral dari perangkat keras, maka akan dikapitalisasi sebagai aset tetap. Namun bila biaya perolehan perangkat lunak bukan bagian integral dari perangkat lunak maka diakui sebagai aset tak berwujud (Kartikahadi et al. 2016).

Menurut PSAK 19 penilaian aset tak berwujud sebagai berikut: (1) Aset tak berwujud yang diperoleh melalui pembelian. Perusahaan mencatat sebesar biaya perolehan atas aset tak berwujud yang dibeli dari pihak lain. Biaya perolehan terdiri dari harga pembelian (termasuk bea masuk dan pajak pembelian yang tidak dapat direstitusi), biaya jasa hukum, dan biaya insidental lainnya. (2) Aset tak berwujud yang diperoleh dalam kombinasi bisnis. Aset tak berwujud yang diperoleh melalui pertukaran saham atau aset lainnya, maka perusahaan mencatat biaya perolehan sebesar nilai wajar dari aset yang dipertukarkan atau nilai wajar dari aset tak berwujud yang diterima, mana yang lebih jelas. (3) Aset tak berwujud yang diperoleh dari hasil pembuatan sendiri. Perusahaan membebankan semua biaya tahap penelitian dan beberapa tahap pengembangan. Biaya pengembangan tertentu dikapitalisasi bila kriteria viabilitas ekonomi terpenuhi (IAI 2018).

Menurut Kieso (2017), jenis-jenis aset tak berwujud diklasifikasikan berikut ini: (1) Aset tak berwujud terkait pemasaran, contoh: Merek/nama dagang, kepala surat kabar, nama domain internet, dan perjanjian nonkompetisi. (2) Aset tak berwujud terkait pelanggan, contoh: daftar pelanggan, pesanan atau backlog produksi, dan hubungan pelanggan kontraktual maupun non kontrak. (3) Aset tak berwujud terkait artistik, contoh: hak cipta atau copyright. (4) Aset tak berwujud terkait kontrak, contoh: waralaba (franchise) dan lisensi. (5) Aset tak berwujud terkait teknologi, contoh: paten. (6) Goodwill. (7) Biaya Penelitian dan Pengembangan (Research and development).

Pelaporan aset tak berwujud dalam laporan posisi keuangan sama dengan aset tetap namun tidak ada akun kontra yang ditampilkan. Pada laporan laba rugi perusahaan harus menyajikan beban amortisasi dan penurunan nilai untuk aset tak berwujud selain goodwill secara terpisah dalam laba neto, biasanya disajikan dalam item baris terpisah.

\section{Amortisasi}

Defini Amortisasi sesuai dengan PSAK 19 (Revisi 2018) adalah "alokasi sistematis jumlah tersusutkan aset tak berwujud selama umur manfaatnya" (IAI 2018). Amortisasi menurut UU No. 36 Tahun 2008 tentang Pajak Penghasilan menyebutkan bahwa "amortisasi dilakukan terhadap pengeluaran untuk memperoleh harta tidak berwujud dan pengeluaran lainnya, termasuk biaya perpanjangan hak guna bangunan, hak guna usaha, hak pakai dan muhibah (goodwill) yang mempunyai masa manfaat lebih dari 1 (satu) tahun yang digunakan untuk mendapatkan, menagih, dan memelihara penghasilan" (Kemensekneg RI 2008).

Sedangkan menurut para ahli, amortisasi di definisikan sebagai berikut: Menurut Jusuf (2011) bahwa amortisasi adalah proses untuk mengalokasikan biaya perolehan aset tak berwujud. Menurut Hermawan et al. (2019) bahwa amortisasi adalah alokasi sistematis dari nilai aset tidak berwujud yang dapat di depresiasikan selama masa manfaat aset tersebut. Dari pengertian tersebut dapat dikatakan bahwa nilai aset tak berwujud akan habis dan harga perolehan aset tak 
berwujud harus diamortisasi secara sistematis selama taksiran masa manfaat, dan tidak boleh dibebankan seluruhnya pada periode perolehan.

Beberapa hal yang perlu dipertimbangkan dalam menaksir masa manfaat aset tak berwujud PSAK Nomor 19 Revisi 2018 adalah sebagai berikut: (a) Ketentuan hukum, peraturan, dan perjanjian yang membatasi masa manfaat maksimum. (b) Kemungkinan untuk memperbarui atau memperpanjang batas masa manfaat yang telah ditentukan. (c) Pengaruh keuangan, permintaan, persaingan, dan faktor perubahan ekonomi dan teknologi yang mempengaruhi masa manfaat. (d) Perkiraan tindakan yang akan dilakukan oleh pesaing, pelaksana hukum atau peraturan dan lainnya yang membatasi keunggulan dalam daya saing (competitive advantage). (e) Adanya masa manfaat yang tidak terbatas dan masa manfaat yang diharapkan tidak dapat ditaksir secara wajar. (f) Kemungkinan aset tak berwujud terdiri atas beberapa jenis atau faktor yang mempunyai masa manfaat yang berbeda (IAI 2018).

Masa manfaat aset tak berwujud dibedakan menjadi dua yaitu: (a) masa manfaat terbatas, aset tak berwujud dengan masa manfaat terbatas harus diamortisasi. Konsep amortisasi untuk aset tak berwujud sama dengan konsep penyusutan yang berlaku untuk aset tetap. Masa manfaat tersebut harus mencerminkan periode selama aset tersebut memberikan manfaat ekonomis bagi entitas. (b) masa manfaat tidak terbatas, suatu aset disebut memiliki masa manfaat tidak terbatas apabila tidak dapat ditentukan masa manfaat dengan periode waktu yang mana dalam periode waktu tersebut entitas dapat memperoleh manfaat ekonomis dari aset tak berwujud tersebut. Masa manfaat tidak terbatas bukan berarti masa manfaat tidak terhingga. Masa manfaat tersebut harus ditentukan berdasarkan rencana pengeluaran masa depan yang dibutuhkan untuk merawat aset pada standar kinerjanya (Martani et al. 2017).

Metode amortisasi yang digunakan dalam akuntansi komersial rumusnya sebagai berikut:

1. Metode Garis Lurus:

(Biaya Perolehan Aset - Nilai Residu)

Masa Manfaat Aset

2. Metode Saldo Menurun:

Nilai Buku Awal Tahun x Tarif Saldo Menurun

3. Metode Unit Produksi:

(Biaya Perolehan Aset - Nilai Residu) x Jam Penggunaan

Estimasi Jam Penggunaan Total

Perhitungan amortisasi juga memerlukan nilai sisa, biasanya diasumsikan sama dengan nol, kecuali ada komitmen dengan pihak ketiga untuk membeli aset tak berwujud pada akhir masa manfaatnya. Sedangkan Rumus metode amortisasi fiskal menurut (Waluyo 2016) sebagai berikut:

1. Metode Garis Lurus:

Biaya Amortisasi = \%Tarif x Harga Perolehan Aset Tak berwujud

2. Metode Saldo Menurun:

Biaya Amortisasi $=2 \mathrm{x}$ Persentase dari Metode Garis Lurus x Nilai Buku.

Metode perhitungan amortisasi dapat dilakukan secara perpajakan melalui:

(a) Konsisten dalam bagian-bagian yang sama setiap tahun selama masa manfaat atau garis lurus. (b) Bagian-bagian yang menurun setiap tahun dengan menerapkan tariff amortisasi atas nilai sisa buku atau saldo menurun (Muljono 
and Wicaksono 2009). Berikut pada Tabel 1 merupakan penentuan tarif amortisasi sesuai dengan UU Perpajakan.

\begin{tabular}{cccc} 
Tabel 1 Kelompok Harta Tidak Berwujud dan Tarif Penyusutan \\
\hline Kelompok Harta & Masa & \multicolumn{2}{c}{ Tarif Amortisasi } \\
Tidak Berwujud & Manfaat & Garis Lurus & Saldo Menurun \\
\hline Kelompok 1 & 4 Tahun & $25 \%$ & $50 \%$ \\
Kelompok 2 & 8 Tahun & $12,5 \%$ & $25 \%$ \\
Kelompok 3 & 16 Tahun & $6,25 \%$ & $12,5 \%$ \\
Kelompok 4 & 20 Tahun & $5 \%$ & $10 \%$ \\
\hline
\end{tabular}

Sumber: (Kemensekneg RI 2008)

\section{Pajak Penghasilan}

Menurut Resmi (2017) bahwa pajak penghasilan (pph) adalah pajak yang dikenakan terhadap subjek pajak atas penghasilan yang diterima atau diperolehnya dalam satu tahun pajak. Sedangkan menurut Supramono and Damayanti (2015) bahwa pajak penghasilan adalah suatu pungutan resmi yang ditujukan kepada masyarakat yang berpenghasilan atau atas penghasilan yang diterima atau diperoleh dalam tahun pajak untuk membiayai pengeluaran-pengeluaran Negara.

Pajak penghasilan yang terutang dihitung dengan mengalikan tarif tertentu terhadap dasar pengenaan pajak. Dasar pengenaan pajak (DPP) biasa disebut dengan Penghasilan Kena Pajak (PKP) (Rahayu 2019). Penghasilan Kena Pajak (PKP) (taxable income) merupakan laba yang dihitung berdasarkan peraturan perpajakan yang berlaku (Suandy 2016). Penghasilan Kena Pajak atau sering disingkat PKP adalah dasar yang digunakan untuk menghitung besarnya pajak terutang (Susyanti and Dahlan 2015).

PKP atau Laba Kena Pajak dapat dihitung dengan menggunakan pembukuan. Perhitungan PKP untuk Wajib Pajak Badan dapat menggunakan rumus sebagai berikut: $\mathrm{PKP}=$ penghasilan neto, atau penghasilan bruto - biaya yang diperkenankan UU PPh (Mardiasmo 2016). Sedangkan rumus untuk menghitung pajak penghasilan yaitu: $\mathrm{PPh}$ Badan $=$ Tarif $\mathrm{x}$ Laba Kena Pajak (Tindagi and Morasa 2014).

Berdasarkan No. SE-66/PJ/2010 tentang penegasan pada pasal $31 \mathrm{E}$ ayat 1 UU PPh. Penerapan tarif dibedakan menjadi: (1) Wajib Pajak Badan Dalam Negeri dengan peredaran bruto tidak melebihi jumlah Rp 4.800.000.000, tarifnya yaitu $12,5 \%$ (diperoleh dari 50\% x 25\%). (2) Wajib Pajak dengan peredaran bruto melebihi Rp 4.800.000.000 dan tidak melebihi Rp 50.000.000.000, dengan langkah-langkah sebagai berikut: (a) (Rp 4.800 .000 : peredaran bruto) $\mathrm{x}$ total Penghasilan Kena pajak = hasil. (b) Hasil x tarif 12,5\%. (c) Sebagian penghasilan kena pajak lainnya setelah dikurangi tarif diatas dikalikan dengan tarif $25 \%$. (3) Wajib pajak badan dengan peredaran bruto melebihi Rp 50.000.000.000. seluruh penghasilan kena pajak dikalikan dengan tariff 25\% (Rahayu 2019).

\section{Koreksi Fiskal}

Koreksi fiskal harus dilakukan Wajib Pajak ketika menghitung besarnya $\mathrm{PPh}$ terutang pada akhir tahun. Apabila koreksi fiskal tidak dilakukan oleh Wajib Pajak, maka akan menimbulkan kesalahan dalam ketentuan pengakuan dan tata cara perhitungannya. Dengan adanya koreksi fiskal tersebut akan mempermudah 
perhitungan Penghasilan Kena Pajak sesuai dengan Peraturan PerundangUndangan Perpajakan. Hal-hal yang menyebabkan adanya koreksi fiskal: (1) Adanya perbedaan antara SAK dan peraturan perpajakan. (2) Adanya kompensasi kerugian fiskal. (3) Nilai yang tidak wajar karena adanya hubungan istimewa (Sambodo 2015).

Melalui koreksi fiskal maka besarnya Penghasilan Kena Pajak secara komersial dan secara fiskal dapat berbeda. Perbedaan tersebut akibat adanya koreksi yang dapat berupa: (1) Koreksi positif, koreksi karena adanya perbedaan antara ketentuan perpajakan dengan komersial yang mengakibatkan Penghasilan Kena Pajak bertambah besar. (2) Koreksi negatif, koreksi karena adanya perbedaan antara ketentuan perpajakan dengan komersial yang mengakibatkan Penghasilan Kena Pajak bertambah kecil (Suandy 2016).

\section{METODE PENELITIAN}

Metode penelitian merupakan rancangan penelitian yang meliputi langkahlangkah penelitian, waktu penelitian, sumber data dan analisa data (Sujarweni 2015). Metode yang digunakan dalam penelitian ini yaitu penelitian evaluasi. Sedangkan jenis penelitian ini yaitu penelitian kualitatif. Ruang lingkup dalam pembahasan penelitian ini yaitu mengevaluasi pengakuan aset tak berwujud yang dimiliki oleh PT. Petrokopindo Cipta Selaras Gresik sesuai dengan PSAK 19, serta membandingkan metode amortisasi atas aset tak berwujud secara komersial dengan metode amortisasi fiskal serta hasilnya terhadap pajak penghasilan tahun 2019.

Sumber data yang digunakan dalam penelitian ini adalah data primer. Data primer yang digunakan dalam penelitian ini yaitu sejarah serta struktur organisasi perusahaan dan data yang diperlukan dalam penelitian ini berupa daftar aset tetap tak berwujud, laporan laba rugi dan pendapatan komprehensif lainnya konsolidasian pada tahun 2019. Sedangkan jenis data yang digunakan adalah Data Kualitatif, yang digunakan yaitu berupa sejarah singkat, struktur organisasi perusahaan dan pengakuan perolehan aset tak berwujud. Data Kuantitatif, yang digunakan berupa data yaitu daftar aset tetap, metode perhitungan amortisasi, laporan laba rugi dan pendapatan komprehensif lainnya konsolidasian pada tahun 2019.

Teknik pengunpulan data merupakan langkah yang paling utama dalam penelitian, karena memiliki tujuan untuk mendapatkan data. Teknik pengumpulan data dapat dilakukan melalui observasi, wawancara, kuesioner, dokumentasi dan gabungan dari keempatnya (Sugiyono 2014). Tehnik pengumpulan data yang digunakan dalam penelitian ini sebagai berikut: (1) Wawancara, mengumpulkan data dengan cara melakukan wawancara langsung dengan pihak-pihak yang berkepentingan pada perusahaan PT Petrokopindo Cipta Selaras Gresik, yaitu mengenai gambaran yang berkaitan dengan sejarah singkat perusahaan, struktur organisasinya, pengakuan perolehan aset tak berwujud dan metode perhitungan amortisasi yang digunakan perusahaan. (2) Dokumentasi, mengumpulkan data melalui dokumen atau catatan yang ada diperusahaan tersebut. Data yang digunakan dalam penelitian yaitu data daftar aset tetap tak berwujud, dan laporan laba rugi dan pendapatan komprehensif lainnya konsolidasian pada tahun 2019 . 
Teknik analisis data penelitian ini yaitu deskriptif. Pendekatan penelitian yang dilakukan secara deduktif yaitu membuktikan teori yang sudah ada (Sujarweni 2015). Langkah-langkah dalam penelitian ini sebagai berikut: (1) Mengevaluasi pengakuan aset tak berwujud yang dimiliki perusahaan menurut PSAK 19. (2) Mengevaluasi amortisasi komersial dan amortisasi fiskal metode garis lurus. (3) Menghitung amortisasi komersial dan amortisasi fiskal metode saldo menurun. (4) Rekonsiliasi fiskal (lihat Tabel 2). (5) Menghitung Pajak Penghasilan, Tarif pajak penghasilan bagi wajib pajak badan menggunakan Pasal 17 ayat (1) huruf b Undang-Undang Pajak Penghasilan yaitu dikenakan sebesar 25\% dengan peredaran bruto melebihi jumlah Rp 50.000.000.000 (Sambodo 2015).

Penghasilan Kena Pajak

$\operatorname{Rp} x x x$

PPh Terutang :

Tarif $\mathrm{x}$ PKP

$\operatorname{Rp} x x x$

Kredit Pajak :

PPh Pasal 25

$\operatorname{Rp} \mathrm{xxx}$

PPh Kurang/Lebih Bayar Pasal 29

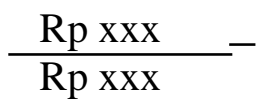

(6) Analisa perbandingan amortisasi fiskal dengan menggunakan metode garis lurus dan saldo menurun untuk mengetahui pajak penghasilan. (7) Interpretasi.

Tabel 2 Rekonsiliasi Fiskal

Laporan Laba Rugi

\begin{tabular}{lccc}
\hline \multicolumn{1}{c}{ Keterangan } & $\begin{array}{c}\text { Menurut } \\
\text { Komersial }\end{array}$ & $\begin{array}{c}\text { Koreksi } \\
\text { Fiskal }\end{array}$ & $\begin{array}{c}\text { Menurut } \\
\text { Fiskal }\end{array}$ \\
\hline Penjualan & $\mathrm{xxx}$ & & $\mathrm{xxx}$ \\
Harga Pokok Penjualan & $\mathrm{xxx}$ & & $\mathrm{xxx}$ \\
Laba Kotor & $\mathrm{xxx}$ & & $\mathrm{xxx}$ \\
Beban Operasi : & & & \\
Beban Gaji & $\mathrm{xxx}$ & & $\mathrm{xxx}$ \\
$\ldots \ldots \ldots . . .$. & $\mathrm{xxx}$ & & $\mathrm{xxx}$ \\
Beban Penyusutan & $\mathrm{xxx}$ & $(\mathrm{xxx})$ & $\mathrm{xxx}$ \\
Total Beban Operasi: & $\mathrm{xxx}$ & $(\mathrm{xxx})$ & $\mathrm{xxx}$ \\
$\ldots \ldots \ldots \ldots \ldots . .$. & & & \\
Laba Rugi Operasi & $\mathrm{xxx}$ & $\mathrm{xxx}$ & $\mathrm{xxx}$ \\
Pendapatan Lain-Lain & $\mathrm{xxx}$ & $(\mathrm{xxx})$ & $\mathrm{xxx}$ \\
Total Pendapatan Lain-Lain & $\mathrm{xxx}$ & $(\mathrm{xxx})$ & $\mathrm{xxx}$ \\
Laba Bersih & $\mathrm{xxx}$ & $\mathrm{xxx}$ & $\mathrm{xxx}$ \\
\hline Sumber: (Suandy 2016) & & &
\end{tabular}

\section{HASIL DAN PEMBAHASAN PENELITIAN}

Mengevaluasi Pengakuan Aset Tak Berwujud Yang Dimiliki Perusahaan

Dari hasil penelitian diperoleh data Aset Tak Berwujud yang dimiliki oleh PT Petrokopindo Cipta Selaras Gresik, tersaji pada Tabel 3. 
Tabel 3 Daftar Aset Tetap Tak Berwujud

\begin{tabular}{ll}
\hline Keterangan & : Sistem InformasiKepegawaian \\
Tipe Aset & : Tidak Berwujud \\
Harga Perolehan & : Rp 35.000.000 \\
Tanggal Perolehan & $:$ 31 Desember 2018 \\
Estimasi Umur & $:$ 4 Tahun \\
\hline Sumber: PT. Petrokopindo Cipta Selaras Gresik
\end{tabular}

Berdasarkan hasil wawancara dengan pihak PT. Petrokopindo Cipta Selaras Gresik aset tak berwujud yang dimiliki tersaji dalam Tabel 3. Aset tak berwujud tersebut tergolong perangkat lunak berupa Sistem Informasi Kepegawaian yang diperoleh dari pembelian kepada pihak lain dan seluruh biaya yang dikeluarkan untuk memperoleh Sistem Informasi Kepegawaian tersebut sepenuhnya di akui sebagai aset tak berwujud sebesar Rp 35.000.000. Estimasi manfaat pemakaian dari aset tersebut diharapkan 4 Tahun. Sesuai dengan kriteria pengakuan aset tak berwujud menurut PSAK 19 dan sejalan dengan hasil penelitian (Sofia 2018) yang menyatakan biaya situs web diakui sebagai aset tak berwujud bukan beban seperti hasil penelitian yang dilakukan oleh (Firmansyah and Hartanto 2019).

\section{Mengevaluasi Amortisasi Komersial Dan Amortisasi Fiskal Metode Garis Lurus (Straight Line Method)}

Perhitungan biaya amortisasi secara komersial menggunakan garis lurus: Biaya amortisasi $=\operatorname{Rp} 35.000 .000: 4=\operatorname{Rp}$ 8.750.000. Perhitungan biaya amortisasi secara fiskal menggunakan garis lurus: Biaya amortisasi tahun $2019=25 \% \mathrm{x} \mathrm{Rp}$ 35.000.000 $=\mathrm{Rp}$ 8.750.000. Perusahaan menggunakan metode garis lurus sehingga sudah sesuai dengan PSAK 19 dan peraturan perpajakan, sehingga tidak ada koreksi fiskal karena hasil amortisasi sama antara komersial dengan fiskal yaitu Rp 8.750.000.

\section{Menghitung Amortisasi Komersial Dan Amortisasi Fiskal Metode Saldo Menurun (Declining Balance Method)}

Perhitungan biaya amortisasi komersial menurut PSAK 19 adalah sebagai berikut: Biaya Amortisasi $=\operatorname{Rp~35.000.000~x~50\% ~}=$ Rp 17.500.000. Perhitungan biaya amortisasi Fiskal menurut UU PPh adalah sebagai berikut: Biaya Amortisasi tahun pertama pada $2019=2 \times 25 \%$ x Rp 35.000.000 = Rp 17.500.000. Metode Saldo Menurun sesuai dengan PSAK 19 dan diperbolehkan menurut peraturan perpajakan, sehingga tidak ada koreksi fiskal karena hasil amortisasi sama antara komersial dengan fiskal yaitu Rp 17.500.000.

\section{Rekonsiliasi Fiskal}

Berdasarkan Tabel 4, perhitungan aset tak berwujud menggunakan metode garis lurus sudah dilakukan koreksi fiskal oleh perusahaan dan tidak ada perbedaan antara amortisasi komersial dengan amortisasi fiskal karena tarif dan metode yang digunakan sudah sesuai dengan ketentuan peraturan perundangundangan perpajakan. PKP yang diperoleh sebesar Rp 27.425.574.392. Kemudian perhitungan aset tetap tak berwujud diatas dengan menggunakan metode saldo menurun tidak ada perbedaan antara amortisasi komersial dengan amortisasi fiskal 
karena tarif dan metode yang digunakan sudah sesuai dengan ketentuan peraturan perundang-undangan perpajakan. PKP yang diperoleh sebesar Rp 27.416.824.392.

\section{Tabel 4 Rekonsiliasi Fiskal \\ PT. Petrokopindo Cipta Selaras}

Laporan Laba Rugi Dan Pendapatan Komprehensif Lainnya Konsolidasian

Untuk Tahun Yang Berakhir 31 Desember 2019

(Dinyatakan dalam Rupiah, kecuali dinyatakan lain)

\begin{tabular}{|c|c|c|c|}
\hline Keterangan & Menurut Komersial & $\begin{array}{c}\text { Koreksi } \\
\text { Fiskal }\end{array}$ & Menurut Fiskal \\
\hline Penjualan & 502.376 .002 .579 & & 502.376 .002 .579 \\
\hline \multicolumn{4}{|l|}{ Beban Pokok Penjualan } \\
\hline \multirow[t]{2}{*}{ Laba Kotor } & $(447.472 .572 .631)$ & & $(447.472 .572 .631)$ \\
\hline & 54.903 .429 .948 & & 54.903 .429 .948 \\
\hline \multicolumn{4}{|l|}{ Beban Usaha } \\
\hline Umum Dan Administrasi(*) & $(22.467 .033 .621)$ & 0 & $(22.467 .033 .621)$ \\
\hline Pemasaran & $(287.405 .162)$ & & $(287.405 .162)$ \\
\hline Jumlah beban usaha & $(22.754 .438 .783)$ & & $(22.754 .438 .783)$ \\
\hline Laba usaha & 32.148 .991 .165 & & 32.148 .991 .165 \\
\hline Beban Keuangan & $(6.636 .674 .210)$ & & $(6.636 .674 .210)$ \\
\hline \multirow{2}{*}{$\begin{array}{l}\text { Laba Usaha Setelah Beban } \\
\text { Keuangan }\end{array}$} & & & \\
\hline & 25.512 .316 .955 & & 25.512 .316 .955 \\
\hline \multicolumn{4}{|l|}{ Penghasilan (Beban) Lain-Lain } \\
\hline \multicolumn{4}{|l|}{ Pendapatan Lain-Lain } \\
\hline Beban Lain-Lain & 1.904.507.437 & & 1.904.507.437 \\
\hline \multirow[t]{2}{*}{ Penghasilan (Beban) Lain-Lain } & - & & - \\
\hline & 1.904 .507 .437 & & 1.904 .507 .437 \\
\hline Laba Sebelum Pajak Penghasilan & 27.416.824.392 & & 27.416 .824 .392 \\
\hline
\end{tabular}

\section{Menghitung Pajak Penghasilan}

1. Metode Garis Lurus (Straight Line Method)

Penghasilan Kena Pajak = Rp 27.425.574.392

$\mathrm{PPh}$ Terutang :

$25 \%$ x Rp 27.425.574. 392

Kredit pajak

PPh Kurang/Lebih Bayar Pasal 29

2. Metode Saldo Menurun (Declining Balance Method)

Penghasilan Kena Pajak $(\mathrm{PKP})=$ Rp 27.416.824.392

PPh Terutang :

$25 \%$ x Rp 27.416.574. 392

$=\operatorname{Rp} 6.854 .143 .598$

Kredit pajak

PPh Kurang/Lebih Bayar Pasal 29

$$
\begin{aligned}
& =\operatorname{Rp} 6.856 .393 .598 \\
& \underline{\operatorname{Rp} 571.366 .133}- \\
& =\operatorname{Rp} 6.285 .027 .465
\end{aligned}
$$

Rp $\quad 571.178 .633$

$=\operatorname{Rp} 6.282 .964 .965$ 


\section{Analisa Perbandingan Metode Amortisasi Fiskal Dengan Menggunakan Metode Garis Lurus Dan Saldo Menurun Untuk Mengetahui Pajak Penghasilan}

Tabel 5 Perbandingan Amortisasi Fiskal Dengan

Menggunakan Metode Garis Lurus Dan Saldo Menurun Untuk Mengetahui Pajak Penghasilan

\begin{tabular}{|c|c|c|c|c|}
\hline Metode & $\begin{array}{c}\text { Biaya } \\
\text { Amortisasi }\end{array}$ & PKP & PPh Terutang & $\begin{array}{c}\text { PPh Kurang } \\
\text { Bayar }\end{array}$ \\
\hline Garis Lur & $\mathrm{Rp} \quad 8.750 .000$ & Rp 27.425.574.392 & $\operatorname{Rp} 6$ & Rp 6.285.027.465 \\
\hline Saldo Me & $\mathrm{Rp} 17.500 .000$ & $\mathrm{Rp} 27.416 .824 .392$ & $\operatorname{Rp} 6.856 .393 .598$ & Rp 6.282.964.965 \\
\hline \multicolumn{4}{|c|}{ Penghematan } & 2.062 .500 \\
\hline
\end{tabular}

Berdasarkan Tabel 5, analisis pembahasan biaya amortisasi dihitung dengan menggunakan metode garis lurus. Masa manfaat ditetapkan menurut kelompok satu yaitu empat tahun dengan tarif yaitu $25 \%$ per tahun, sehingga jumlah biaya amortisasi dari tahun perolehan sampai dengan tahun 2019 sebesar Rp 8.750.000 (delapan juta tujuh ratus lima puluh ribu rupiah). Biaya amortisasi dengan menggunakan metode saldo menurun. Masa manfaat ditetapkan menurut kelompok satu yaitu empat tahun dengan tarif 50\% untuk tahun pertama, $25 \%$ untuk tahun kedua, 12,5\% untuk tahun ketiga dan keempat, sehingga jumlah biaya amortisasi pada tahun 2019 sebesar Rp 17.500.000 (tujuh belas juta lima ratus ribu rupiah). Pada tahun berikutnya akan ada penurunan persentase tarif sehingga memicu penurunan pembebanan amortisasi dan menaikan laba komersial ditahun selanjutnya. Biaya amortisasi aset tak berwujud setelah dilakukan koreksi fiskal yaitu tarif dan metode yang digunakan sudah sesuai dengan ketentuan peraturan perundang-undangan perpajakan.

Adanya perbedaan jumlah biaya amortisasi diatas yang merupakan beda waktu yang bersifat sementara dapat dimanfaatkan untuk melakukan perhitungan pajak penghasilan. Perhitungan Pajak Penghasilan perusahaan PT Petrokopindo Cipta Selaras atas Wajib Pajak Badan menurut tarif pasal 17 ayat (1) huruf b. Nilai Penghasilan Kena Pajak jika menggunakan metode garis lurus yaitu senilai Rp 27.425.574.392 sehingga perhitungan Pajak Penghasilan menurut tarif pasal 17 ayat (1) huruf b senilai Rp 6.285.027.465. Nilai Penghasilan Kena Pajak jika menggunakan metode saldo menurun senilai Rp 27.416.824.392. Sehingga perhitungan Pajak Penghasilan menurut tarif pasal 17 ayat (1) huruf b senilai Rp 6.282.964.965 jika dilihat dari perhitungan Pajak Penghasilan untuk tahun 2019 terdapat penghematan pajak jika menggunakan metode saldo menurun yaitu senilai Rp 2.062.500. Sehingga metode saldo menurun sangat sesuai digunakan saat kondisi perekonomian sedang lesu seperti saat ini karena dampak covid-19. Penghematan pajak tersebut bisa dimanfaatkan perusahaan untuk menjalankan operasional usaha demi kelangsungan usaha.

\section{Interpretasi}

Aset tak berwujud yang dimiliki PT. Petrokopindo Cipta Selaras berupa Sistem Informasi Kepegawaian yang termasuk kriteria sebagai aset tak berwujud karena tergolong sebagai perangkat lunak yang bukan bagian integral dari perangkat komputer maka pengakuan atas Sistem Informasi Kepegawaian tersebut sepenuhnya di akui sebagai aset tak berwujud sebesar harga belinya yaitu Rp 
35.000.000, sesuai dengan PSAK 19. Sedangkan pembebanan amortisasi pada tahun pertama menggunakan metode garis lurus sebesar Rp 8.750.000,- dan PKP yang diperoleh setelah rekonsiliasi fiskal sebesar Rp 27.425.574.392, sehingga pajak penghasilan yang dibayar Rp 6.285.027.465. sedangkan pembebanan amortisasi pada tahun pertama menggunakan saldo menurun sebesar $\mathrm{Rp}$ 17.500.000 dan PKP yang diperoleh setelah rekonsiliasi fiskal sebesar Rp 27.416.824.392, sehingga pajak penghasilan yang dibayar Rp 6.282.964.965, pada tahun berikutnya akan ada penurunan prosentase tarif sehingga memicu penurunan pembebanan amortisasi dan menaikan laba komersial ditahun selanjutnya. Namun pada tahun pertama ini jika menggunakan metode saldo menurun teridentifikasi penghematan pajak senilai Rp 2.062.500. Sehingga metode saldo menurun sangat sesuai digunakan saat kondisi perekonomian sedang lesu seperti saat ini karena dampak covid-19. Penghematan pajak tersebut bisa digunakan sebagai penambah modal perusahaan untuk menjalankan operasional usaha. Hasil penelitian ini sejalan dengan penelitian yang dilakukan oleh (Firmansyah et al. 2020) yang menyatakan penggunaan metode garis lurus untuk penyusutan aset tak berwujud seperti piranti lunak dan lisensi akan menghasilkan laba komersial lebih banyak. Sedangkan penelitian (Ainiyah 2018) menghasilkan besarnya laba sebelum pajak atau PKP mempengaruhi besarnya pajak penghasilan. Jika PKP besar maka pajak penghasilan yang akan dibayar juga besar, sebaliknya jika PKP rendah maka pajak yang dibayar juga akan lebih hemat.

\section{KESIMPULAN}

Pengakuan Aset tak berwujud sudah sesuai dengan kriteria yang ada dalam PSAK 19. PT. Petrokopindo Cipta Selaras dalam pembebanan amortisasi menggunakan metode garis lurus. Masa manfaat yang ditetapkan menurut kelompok satu yaitu empat tahun dengan tarif yaitu $25 \%$ per tahun, biaya amortisasi aset tak berwujud tidak dilakukan koreksi fiskal karena tarif dan metode yang digunakan sudah sesuai dengan ketentuan peraturan perundangundangan perpajakan. Adanya perbedaan amortisasi fiskal dengan menggunakan metode garis lurus dan saldo menurun atas aset tak berwujud terhadap pajak penghasilan, sehingga akan mengurangi Penghasilan Kena Pajak. Penghasilan Kena Pajak yang berkurang akan berpengaruh terhadap Pajak Penghasilan, jika dilihat dari perhitungan Pajak Penghasilan untuk tahun 2019 terdapat penghematan pajak jika menggunakan metode saldo menurun yaitu senilai $\mathrm{Rp}$ 2.062.500. Sehingga penghematan tersebut bisa digunakan untuk operasional perusahaan.

Perusahaan PT Petrokopindo Cipta Selaras sudah benar dalam melakukan Pengakuan aset tak berwujud, pembukuannya, metode dan tarif yang digunakan sudah sesuai dengan peraturan perpajakan. Terlihat biaya amortisasi pada tahun 2019 lebih besar sehingga dalam perhitungan pajak penghasilan lebih hemat menggunakan metode saldo menurun. Dalam perpajakan ini terkait beda waktu pembebanan. Metode saldo menurun sangat sesuai jika digunakan dalam kondisi perekonomian sedang merosot seperti saat ini dampak dari covid-19. Diharapkan dari hasil penelitian ini bermanfaat bagi perusahaan dalam menentukan aset tak berwujud serta dapat digunakan sebagai bahan masukan mengenai metode, masa 
manfaat dan tarif sesuai dengan ketentuan Peraturan Perundang-Undangan Perpajakan dalam rangka penghematan Pajak Penghasilan. Bagi peneliti selanjutmya diharapkan lebih memperluas penelitian dengan melakukan penelitian pada perusahaan lain dengan sektor yang berbeda, dengan harapan memperoleh temuan yang berbeda.

\section{DAFTAR PUSTAKA}

Ainiyah, Nur. 2018. “Analisis Penerapan Koreksi Fiskal atas Pendapatan, Beban dan Pajak Tangguhan untuk Menghitung Pajak Penghasilan Terutang Pada PT. Sinar Karya Bahagia". Prive: Jurnal Riset Akuntansi Dan Keuangan 1 (1): 59-72. http://ejurnal.unim.ac.id/index.php/prive/article/view/142.

Bohari. 2012. Pengantar Hukum Pajak (9th ed.). Jakarta: PT. RajaGrafindo Persada.

Dewi, Anak Agung Istri Shintia, and Putu Ery Setiawan. 2015. "Penerapan Tax Review Atas Pajak Penghasilan". E-Jurnal Akuntansi Universitas Udayana $13 \quad$ (2): 513-531. https://ocs.unud.ac.id/index.php/Akuntansi/article/view/12205.

Firmansyah, Amrie and Lugas Hartanto. 2019. "Kapitalisasi Aset Tak Berwujud Yang Dihasilkan Secara Internal Oleh Start Up Company". JIA : Jurnal Info Artha $\quad 3 \quad$ (1): 29-41. http://jurnal.stan.ac.id/index.php/JIA/article/view/497.

Firmansyah, Amrie, Annisa Kurnia Sari, and Yasmin Putri Maharani. 2020. "Implementasi Aset Tak Berwujud PT. Telekomunikasi Indonesia (Persero) Tbk". BISNIS NET: Jurnal Ekonomi Dan Bisnis 3 (1): 52-61. http://jurnal.dharmawangsa.ac.id/index.php/bisnet/article/view/689.

Firmansyah, Dwi, and Nurwati. 2020. "Analisis Penerapan Perencanaan Pajak Melalui Metode Penyusutan Aset Tetap Untuk Efisiensi Pembayaran Pajak di PT. Dapur Sarwo Ono". IJEA: Indonesian Journal Of Economics Application $\quad 2 \quad$ (1): $\quad 16-23 . \quad$ http://ojs.itbad.ac.id/index.php/IJEA/article/view/366.

Hermawan, Sigit, Biduri, Wiwit Hariyanto, and Ruci A. Rahayu. 2019. Akuntansi Perusahaan Jasa, Dagang, Dan Manufaktur. Sidoarjo: Indomedia Pustaka.

Ikatan Akuntan Indonesia. 2018. Pernyataan Standar Akuntansi Keuangan (PSAK). Jakarta: Dewan Standart Akuntansi Keuangan.

Imaningarti, Sri, and Novita Sari. 2015. "Pengaruh Goodwill, Research Development (RnD), dan Intellectual Capital Terhadap Nilai Pasar Perusahaan”. JIMAT: Jurnal Ilmu Manajemen Dan Akuntansi Terapan 6 (2): 108-121. http://jurnal.stietotalwin.ac.id/index.php/jimat/article/view/105.

Jusuf, Al Haryono. 2011. Dasar-Dasar Akuntansi 7 Jilid 2. Yogyakarta: Sekolah Tinggi Ilmu Ekonomi YKPN.

Kartikahadi, Hans, Rosita Uli Sinaga, Merlyana Syamsul, Sylvia Veronika Siregar, and Ersa Tri Wahyuni. 2016. Akuntansi Keuangan Berdasarkan SAK Berbasis IFRS, (IAI, Ed.) (Edisi 2). Jakarta: IAI. 
Kementerian Sekretariat Negara Republik Indonesia. 2008. Undang-Undang Republik Indonesia Nomor 36 Tahun 2008 Tentang Perubahan Keempat Atas Undang-Undang Nomor 7 Tahun 1983 Tentang Pajak Penghasilan. Jakarta. https://pajak.go.id/.

Kieso, Weygandt. 2017. Akuntansi Keuangan Menengah Intermediate Accounting (IFRS). Jakarta Selatan: Salemba Empat.

Mardiasmo. 2016. Perpajakan. Yogyakarta: Andi.

Martani, Dwi., Sylvia Veronica Ratna Wardhani, Aria Farahmita, and Edward Tanujaya. 2017. Akuntansi Keuangan Menengah Berbasis PSAK (Buku 1). Jakarta: Erlangga.

Muljono, Djoko and Baruni Wicaksono. 2009. Akuntansi Pajak Lanjutan. Yogyakarta: Andi.

Rahayu, Puji. 2019. Perpajakan Disesuaikan dengan Peraturan Perpajakan Terbaru. Sidoarjo: Indomedia.

Resmi, Siti. 2017. Perpajakan (Teori \& Kasus). (M. Masykur, Ed.) (1st ed.). Jakarta Selatan: Salemba Empat.

Riahi, Ahmed, and Belkaoui. 2011. Accounting Teori (5 Buku 1). Jakarta: Salemba Empat.

Rori, Handri. 2013. "Analisis Penerapan Tax Planning Atas Pajak Penghasilan Badan". Jurnal EMBA: Jurnal Riset Ekonomi, Manajemen, Bisnis Dan Akuntansi 1 (3): 410-418. https://ejournal.unsrat.ac.id/index.php/emba/article/view/1840.

Sambodo, Agus. 2015. Pajak Dalam Entitas Bisnis. Jakarta: Salemba Empat.

Setijawan, Imam. 2011. "Pengaruh Aset Tidak Berwujud Terhadap Nilai Perusahaan". Jurnal Ilmiah Aset 13 (2): 139-154. https://widyamanggala.ac.id/journal/index.php/jurnalaset/article/view/80.

Sofia, Ana. 2018. Analisis Perlakuan Akuntansi Untuk Biaya Situs Web Di PT selecta kota batu jawa timur. Skripsi Universitas Islam Negeri Maulana Malik Ibrahim. http://etheses.uin-malang.ac.id/12305/1/14520113.pdf.

Suandy, Erly. 2016. Perencanaan pajak (6th ed.). Jakarta: Salemba Empat.

Sugeng, Bardjo. 2011. "Pengaruh Perencanaan Pajak Terhadap Efisiensi Beban Pajak Penghasilan”. Jurnal Riset Akuntansi Dan Bisnis 11 (2): 122-139. http://jurnal.umsu.ac.id/index.php/akuntan/article/view/406.

Sugiyono. 2014. Metode Penelitian Bisnis. Bandung: Alfabeta.

Sujarweni, V. Wiratna. 2015. Metodologi Penelitian Bisnis dan Ekonomi. Yogyakarta: Pustaka Baru Press.

Supramono, and Theresia Woro Damayanti. 2015. Perpajakan Indonesia (Mekanisme \& Perhitungan). (R. Fiva, Ed.) (Revisi). Yogyakarta: Andi.

Suryandari, Erni, and Putria Yunitha. 2011. "Pengaruh Amortisasi Goodwill Terhadap Kegunaan Informasi Laba Pada Perusahaan Manufaktur". Journal of Accounting And Invesment 12 (1): 100-109. https://journal.umy.ac.id/index.php/ai/article/view/674.

Susyanti, Jeni, and Ahmad Dahlan. 2015. Perpajakan Untuk Praktisi Dan Akademisi. Malang: Empatdua Media.

Tindagi, Rayzah, and Jenny Morasa. 2014. "Analisis Perhitungan Pajak Penghasilan Badan Pada PT. Golden Mitra Inti Perkasa”. Jurnal EMBA: Jurnal Riset Ekonomi, Manajemen, Bisnis Dan Akuntansi 2 (2): 10671076. https://ejournal.unsrat.ac.id/index.php/emba/article/view/4487. 
Waluyo. 2016. Akuntansi Pajak (6th ed.). Jakarta: Salemba Empat.

Warren, Carls S., James M. Reeve, and Jonathan Duchac. 2014. Pengantar Akuntansi (25th ed.). Jakarta Pusat: Salemba Empat.

Wijaya, Calvina Amanda, and Purnamawati Helen Widjaja. 2019. "Penerapan Rekonsiliasi Fiskal Pada Laporan Keuangan PT XYZ Dalam Menghitung Pajak Penghasilan Terutang”. Jurnal Paradigma Akuntansi 1 (2): 317-323. https://journal.untar.ac.id/index.php/jpa/article/view/4705. 